\title{
PENGARUH PARTISIPASI ANGGARAN, KOMITMEN ORGANISASI, GAYA KEPEMIMPINAN TERHADAP KINERJA MANAJERIAL
}

\author{
Zuwesty Eka Putri, Ricky Adiguna \\ UIN Syarif Hidayatullah Jakarta
}

\begin{abstract}
The purpose of this research was to analyze about the effect of budgetary participation, organizational commitment, and leadership styles on managerial performance.This is used primary data by the quetionnaries. Questionneries were distrubuted to principal, vice principal, along with his staff involved in the preparation of the budget at a junior high school in South Tangerang as much as 54 quetionnaries. Number of quetionnaries returned was 43 quetionnaries. Sampling method used convinience sampling. The analysis method to examine bypothesis was regression analysis From the results of multiple regression, generate bypotheses such as the following, that is: 1) Participation budget significant influence on managerial performance, 2) Organizational Commitment significant influence on managerial performance, 3) Leadership style have no significant influence on managerial performance, 4) Budgetary participation, Organizational Commitment, and leadership styles similarity significant influence on managerial performance.
\end{abstract}

Keywords : Budget participation, organizational commitment, leadership styles, managerial performance and multiple regression analysis.

\section{PENDAHULUAN}

Lingkungan persaingan global sekarang ini yang diliputi banyak ketidakpastian, maka perlu menciptakan kondisi ekonomi yang lebih fleksibel dan inovatif dengan mempertimbangkan faktor-faktor ekstern organisasi yang semakin sulit diprediksi. Setiap organisasi baik sektor publik maupun swasta memerlukan system pengendalian manajemen yang menjamin tercapainya tujuan organisasi secara efektif dan efisien. Untuk menjalankan fungsi pengendalian tersebut, manajemen memerlukan suatu alat yang dapat membantunya dalam mengevaluasi kinerja manajer-manajer pada berbagai tingkat pusat pertanggungjawaban yang lebih rendah. Alat tersebut dikenal dengan anggaran.

Anggaran merupakan elemen sistem pengendalian manajemen yang berfungsi sebagai alat perencanaan dan pengendalian agar manajer dapat melaksanakan kegiatan organisasi secara lebih efektif dan efisien. Sebagai alat perencanaan, anggaran merupakan rencana kegiatan yang terdiri dari sejumlah target yang akan dicapai oleh manajer departemen suatu perusahaan dalam melaksanakan serangkaian kegiatan tertentu pada masa yang akan datang. Fungsi anggaran selain sebagai alat pengendali juga sebagai alat untuk mengkoordinasikan, mengkomunikasikan, memotivasi, dan mengevaluasi prestasi (Sarjana, dkk 2012:64).

Siegel (1989) dalam (Indarto dan Ayu, 2011:1) menyatakan bahwa anggaran mempunyai dampak langsung terhadap manusia terutama bagi yang terlibat langsung dalam penyusunan anggaran. Adanya partisipasi dalam penyusunan anggaran menyebabkan sikap respek bawahan 
terhadap pekerjaan dan perusahaan (Milani, 1975 dalam Indarto dan Ayu, 2011:1). Dengan demikian, akan mendorong bawahan yang berpartisipasi untuk membantu atasan dengan memberikan informasi yang dimilikinya sehingga anggaran yang disusun lebih akurat (Baiman, 1982 dalam (Indarto dan Ayu, 2011:1). Keakuratan anggaran diharapkan akan mampu meningkatkan kinerja manajerial (Indarto dan Ayu, 2011:1).

Tetapi, dewasa ini tuntutan akuntanbilitas dan transparansi dalam setiap aspek kehidupan, termasuk tuntutan akuntanbilitas dan transparansi atas lembaga-lembaga publik, salah satunya seperti sekolah di kalangan masyarakat semakin hari semakin membesar. Sekolah dituntut untuk dapat melakukan konsep penganggaran yang baik, oleh karena itu seorang pimpinan di sekolah dalam hal ini kepala sekolah sebagai pengambil kebijakan dituntut untuk dapat sungguh-sungguh memahami mengenai bagaimana penataan keuangan sekolah yang baik dan benar, mengatur sumber daya organisasi, menetapkan orang-orang yang tepat dan kompeten dibidangnya, menjaga hubungan baik dengan para pekerja yang satu dengan yang lain agar tujuan yang diinginkan dapat tercapai.

Penelitian yang membahas mengenai patisipasi penyusunan anggaran terhadap kinerja manajerial telah banyak dilakukan dan menunjukkan hasil yang bertentangan. Saat ini beberapa hasil penelitian menunjukkan hasil yang tidak konsisten. Penelitian yang dilakukan oleh Bass dan Levitt (1963), schuler dan Kim (1979), Brownwll (1982), Brwonell dan Mc Ines (1986), Chenhall dan Brownell (1988), Frucot Shearon (1991), Erly (1985), Steers (1975), Indiantoro (1993) menunjukkan hasil positif dan signifikan antara pastisipasi anggaran terhadap kinerja manajerial (Cahyaning, 2000; Supriyono, 2004; Indarto dan Ayu, 2011). Penelitian yang dilakukan Latham dan Marshall (1982), Latham dan Yuki (1976) menunjukkan hubungan positif yang tidak signifikan (Supriyono, 2004; Indarto dan Ayu, 2011). Namun disisi lain, penelitian yang dilakukan oleh Milani (1975), Kenis (1979), Brownell dan Hirst (1986), Riyanto (1996) justru menunjukkan hubungan yang tidak signifikan. Bahkan beberapa penelitian justru menunjukkan pengaruh negatif baik secara signifikan maupun tidak. Penelitian Cambell dan Gingrich (1986), Ivancevich (1977) menunjukkan pengaruh negatif signifikan. Penelitian yang dilakukan Dosett, Latam dan Mitchell (1979), Mia (1988) mendukung hasil tersebut meskipun tidak signifikan (Indarto dan Ayu, 2011:33). Sedangkan berkaitan dengan variabel komitmen organisasi, penelitian Randall (1990) dalam Nouri dan Parker (1998) menunjukkan komitmen organisasi sebagai variabel moderating mempengaruhi secara signifikan hubungan partisipasi anggaran terhadap kinerja manajerial (Sardjito dan Muthaher ,2007:3). Menurut Mathieu dan Zajac (1990) dalam Sugioko (2007:53) komitmen organisasi adalah ikatan keterkaitan individu dengan organisasi. Menurut Fibrianti dan Riharjo (2013:109) komitmen menunjukkan keyakinan dan dukungan yang kuat terhadap nilai dan sasaran (goal) yang ingin dicapai oleh organisasi, bagi 
individu berkomitmen tinggi, pencapaian tujuan organisasi merupakan hal penting yang harus dicapai serta berpandangan positif dan berbuat yang terbaik untuk kepentingan organisasi.

Untuk menghasilkan sebuah anggaran yang efektif, manajer membutuhkan kemampuan untuk memprediksi masa depan, dengan mempertimbangkan berbagai faktor, seperti faktor partisipasi dan gaya kepemimpinan serta dalam perusahaan tersebut. Keberhasilan dalam mengelola suatu organisasi tidak lepas dari faktor kepimpinan dan sikap bawahan dalam melaksanakan tugas mencapai tujuan organisasi. Menurut Decoster dan Fertakis (1968) dalam Noor (2007:4) kepemimpinan yang efektif harus memberikan pengarahan terhadap usaha-usaha dalam mencapai tujuan organisasi. Keberhasilan dalam mengelola suatu organisasi tidak lepas dari faktor kepemimpinan dan sikap bawahan dalam melaksanakan tugas mencapai tujuan organisasi. Gaya kepemimpinan (leadership style) menggambarkan perilaku manajer dalam menghadapi atau berinteraksi dengan situasi. Menurut De Coster dan Fertakis (1986) dalam Noor (2007:7) gaya kepemimpinan dapat dibagi dalam dua dimensi yaitu, struktur inisiatif (initiating structure) dan gaya kepemimpinan pertimbangan (consideration).

Berdasarkan uraian diatas, maka penulis termotivasi untuk melakukan penelitian ini untuk mengetahui faktor-faktor yang yang mempengaruhi kinerja manajerial. Selain itu juga, peneliti ingin mengetahui seberapa besar pengaruh variabel independen mempengaruhi variabel dependen. Berdasarkan uraian dan dengan melihat latar belakang diatas, maka penulis merumuskan masalah penelitian sebagai berikut:

1. Apakah partisipasi anggaran mempunyai pengaruh secara signifikan terhadap kinerja manajerial?

2. Apakah komitmen organisasi mempunyai pengaruh secara signifikan terhadap kinerja manajerial?

3. Apakah gaya kepemimpinan mempunyai pengaruh secara signifikan terhadap kinerja manajerial?

4. Apakah partisipasi anggaran, komitmen organisasi, gaya kepemimpinan mempunyai pengaruh secara simultan terhadap kinerja manajerial?

\section{METODOLOGI PENELITIAN}

\subsection{Ruang Lingkup Penelitian}

Penelitian ini dirancang sebagai salah satu penelitian yang menguji hipotesis dengan menggunakan metode penelitian kausal komparatif yaitu penelitian yang menggambarkan hubungan sebab akibat antara dua variabel atau lebih (Indriantoro dan Bambang, 2002:27). Penelitian ini bertujuan untuk menguji pengaruh variabel independen (Partisipasi Anggaran, Komitmen Organisasi, Gaya Kepemimpinan) Terhadap variabel dependen (Kinerja Manajerial). 
Unit analisis yang digunakan dalam penelitian ini adalah tingkat individual dengan sampel penelitian kepala sekolah, wakil kepala sekolah beserta jajaran yang berperan penting dalam penyusunan anggaran dan kepengurusan sekolah pada Sekolah Menengah Pertama Negeri di wilayah Tangerang Selatan.

\subsection{Metode Penentuan Sampel}

Metode pengambilan sampel dalam penelitian ini menggunakan convenience sampling atau disebut dengan pemilihan sampel berdasarkan kemudahan. Metode ini memilih sampel dari elemen populasi (orang atau kejadian) yang datanya mudah diperoleh peneliti. Elemen populasi yang dipilih sebagai subyek sampel adalah titik terbatas sehingga peneliti memiliki kebebasan untuk memilih sampel yang paling cepat dan murah (Indriantoro dan Supomo, 2002:27).

Sampel pada penelitian ini adalah Sekolah Menengah Pertama baik negeri yang terdapat di Tangerang Selatan. Data penelitian dikumpulkan dengan menyebarkan daftar pertanyaan (kuesioner) yang diantar langsung oleh peneliti ke Sekolah Menengah Pertama.

\subsection{Metode Pengumpulan Data}

Untuk pengumpulan data yang dibutuhkan guna mendukung penelitian ini, peneliti menggunakan metode survei kuesioner. Survei kuesioner merupakan metode survei dengan menggunakan kuesioner penelitian. Kuesioner adalah satu set pertanyaan yang tersusun secara sistematis dan standar sehingga pertanyaan yang sama dapat diajukan kepada setiap respoden. Kuesioner merupakan alat pengumpulan data yang efektif karena dapat diperolehnya data standar yang dapat dipertanggungjawabkan untuk keperluan analisis menyeluruh tentang karakteristik populasi yang diteliti (Supranto, 2000) dalam Kunwaviyah dan Syahruddin (2010:40).

\subsection{Metode Analisis Data}

Menurut Indriantoro dan Supomo (2002:166) analisis data penelitian merupakan bagian dari proses pengujian data setelah tahap penelitian dan pengumpulan data penelitian. Oleh karena itu, setelah semua data-data dalam penelitian ini terkumpul, maka selanjutnya yang dilakukan adalah menganalisis data, metode analisis data yang digunakan pada penelitian ini adalah metode analisis statistik yang perhitungannya dilakukan dengan menggunakan SPSS 20 yang analisisnya terdiri dari:

\subsubsection{Statistik Deskriptif}

Statistik deskriptif memberikan gambaran atau deskripsi suatu data yang dilihat dari nilai rata-rata (mean), standar deviasi, varian, maksimum, minimum, sum, range, kurtosis, dan skewness (kemencengan distribusi) (Ghozali, 2011:19). 


\subsubsection{Uji Kualitas Data}

\section{a. Uji Validitas}

Uji validitas digunakan untuk mengukur sah atau valid tidaknya suatu kuesioner. Suatu kuesioner dikatakan valid jika pertanyaan pada kuesioner mampu untuk mengungkapkan sesuatu yang akan diukur oleh kuesioner tersebut. Pengujian validitas dalam penelitian ini menggunakan Corrected Item-Total dengan $\mathbf{r}$ tabel, untuk degree of fredom $(\mathrm{df})=\mathrm{n}-2$, dalam hal ini $\mathrm{n}$ adalah jumlah sample dan alpha $=0.05$. Jika $\mathrm{r}$ hitung lebih besar dari $\mathrm{r}$ tabel dan nilai positif maka butir pertanyaan atau indikator tersebut dinyatakan valid (Ghozali, 2011:52).

\section{b. Uji Reliabilitas}

Uji reliabilitas digunakan untuk mengukur bahwa variable yang diunakan benar-benar bebas dari kesalahan sehingga menghasilkan hasil yang konsisten meskipun diuji berkali-kali. Hasil uji realibilitas dengan bantuan SPSS akan menghasilkan Cronbach Alpha. Suatu instrumen dapat dikatakan realible (andal) bila memiliki nilai Cronbach Alpha lebih dari 0,70 (Ghozali, 2011:48).

\subsubsection{Uji Asumsi Klasik}

Untuk melakukan uji asumsi klasik atas data primer ini, maka peneliti melakukan uji multikoloniearitas, uji normalitas, dan uji heteroskedastisitas.

\section{a. Uji Multikoloniearitas}

Pengujian multikoloniearitas bertujuan untuk menguji apakah pada model regresi ditemukan adanya korelasi antar variabel bebas (independen). Model regresi yang baik seharusnya tidak terjadi korelasi diantara variabel independen (Ghozali, 20011:105). Untuk mendeteksi adanya problem multiko, maka dapat dilakukan dengan melihat nilai Tolerance dan Variance Inflation Factor (VIF) serta besaran korelasi antar variabel independen.

\section{b. Uji Normalitas}

Uji normalitas bertujuan menguji apakah dalam model regresi variable pengganggu atau residual memiliki distribusi normal. Metode yang lebih handal untuk melihat normalitas residual adalah dengan melihat normal probability plot yang membandingkan distribusi kumulatif dari distribusi normal.

\section{c. Uji Heteroskedastisitas}

Uji heteroskedastisitas bertujuan menguji apakah model regresi terjadi ketidaksamaan varians dari residual satu pengamatan ke pengamatan yang lain. Jika varians dari residual satu pengamatan ke pengamaan yang lain tetap, maka disebut homoskedastisitas dan jika berbeda disebut heteroskedastisitas. Model regresi yang baik adalah homoskedastisitas (Ghozali, 2011:139). 


\subsubsection{Uji Hipotesis}

Metode statistik untuk menguji pengaruh antara satu variabel dependen dan satu atau lebih variabel independen adalah regresi. Model ini digunakan untuk menguji pengaruh dua atau lebih variabel independen terhadap variabel dependen dengan skala pengukuran interval atau rasio dalam suatu persamaan linier (Indriantoro dan Supomo, 2002:211).

Rumus model analisis regresi linear berganda (multiple linear regression):

$$
\mathrm{Y}=\alpha+\beta_{1} \cdot \mathbf{X}_{\mathrm{PP}}+\beta_{2} . \mathrm{X}_{\mathrm{KO}}+\beta_{3} . \mathbf{X}_{\mathrm{GK}}+\mathrm{e}
$$

$$
\begin{aligned}
& \text { Keterangan: } \\
& \begin{array}{ll}
\mathrm{Y} & : \text { kinerja manajerial } \\
\alpha & : \text { adalah kostanta } \\
\beta_{1}, \beta_{2,} \beta_{3} & : \text { koefesien regresi } \\
\mathrm{X}_{\mathrm{PP}} & : \text { partisipasi penganggaran } \\
\mathrm{X}_{\mathrm{KO}} & : \text { komitmen organisasi } \\
\mathrm{X}_{\mathrm{GK}} & : \text { gaya kepemimpinan } \\
\mathrm{E} & : \text { error }
\end{array}
\end{aligned}
$$

Untuk melakukan uji hipotesis atas data primer ini, dapat diuji melalui:

\section{a. Uji Koefisien Determinasi $\left(\mathbf{R}^{2}\right)$}

Koefisien Determinasi $\left(\mathrm{R}^{2}\right)$ pada intinya mengukur seberapa jauh kemampuan variable independen terhadap variable dependen serta seberapa besar pengaruh dari faktor lain yangtidak dimasukkan dalam penelitian. Nilai koefisien determinasi $\left(\mathrm{R}^{2}\right)$ adalah antara 0 (nol) dan 1 (satu). Nilai $\mathrm{R}^{2}$ yang kecil berarti kemampuan variabel-variabel independen dalam menjelaskan variasi variabel dependen amat terbatas.

\section{b. Uji Signifikansi Parameter Individual (Uji Statistik t)}

Uji statistik pada dasarnya menunjukkan sebebrapa jauh pengaruh satu variable independen secara individual dalam menerangkan variasi variable dependen. Untuk menguju hipotesis ini digunakan statistik t dengan kriteria pengambilan keputusan menurut Riduawan dan Kuncoro (2007:64) adalah sebagai berikut:

1. Jika nilai probabilitas 0,05 lebih kecil atau sama dengan nilai probabilitas $\operatorname{Sig}$ atau $(0,05 \leq$ Sig), maka $\mathrm{H}_{0}$ diterima atau $\mathrm{H}_{2}$ ditolak, artinya tidak signifikan.

2. Jika nilai probabilitas 0,05 lebih besar atau sama dengan nilai probabilitas $\operatorname{Sig}$ atau $(0,05 \geq$ Sig), maka $\mathrm{H}_{0}$ ditolak atau $\mathrm{H}_{a}$ diterima, artinya signifikan.

\section{c. Uji Statistik F}

Uji statistik F pada dasarnya menunjukkan apakah semua variable independen yang dimasukkan dalam model mempunyai pengaruh secara bersama-sama terhadap variable 
dependen. Untuk pengujian secara keseluruhan dapat diliha dari tabel Anova yang nantinya akan diperoleh F dan didapat nilai probabilitas (sig).

Jika nilai sig $<0,05$, maka keputusannya adalah $\mathrm{H}_{0}$ ditolak dan $\mathrm{H}_{\mathrm{a}}$ diterima artinya signifikan (Ghozali, 2011:98).

\section{HASIL DAN PEMBAHASAN}

\section{1. Tempat dan Waktu Penelitian}

Penelitian ini dilaksanakan pada sekolah menengah tingkat pertama (SMP), yaitu kepala sekolah, wakil kepala sekolah beserta jajarannya yang terlibat dalam penyusunan anggaran pada smp negeri dan swasta yang berada di wilayah Tangerang selatan

Tabel 3.1

Data Distribusi Sampel Penelitian

\begin{tabular}{|c|c|c|c|}
\hline No & Nama sekolah & $\begin{array}{c}\text { Kuesioner } \\
\text { Dikirim }\end{array}$ & $\begin{array}{c}\text { Kuesioner } \\
\text { Kembali }\end{array}$ \\
\hline 1 & SMPN 3 Tangerang Selatan & 5 & 5 \\
\hline 2 & SMPN 10 Tangerang Selatan & 10 & 10 \\
\hline 3 & SMPN 9 Tangerang Selatan & 5 & 5 \\
\hline 4 & SMPN 13 Tangerang Selatan & 10 & 10 \\
\hline 5 & SMP Nusa Indah Ciputat & 4 & 4 \\
\hline 6 & SMPN 2 Tangerang Selatan & 5 & 5 \\
\hline 7 & SMP Muhammadiyah 22 & 5 & 4 \\
\hline 8 & Smp Islamiyah Ciputat & 10 & 0 \\
\hline & TOTAL & $\mathbf{5 4}$ & $\mathbf{4 3}$ \\
\hline
\end{tabular}

Sumber: Data Primer yang diolah

Dari tabel 3.1 terlihat tabel distribusi kuesioner di 5 SMP Negeri dan 2 SMP Swasta berada di Tangerang Selatan. Adapun gambaran mengenai total pengiriman dan pengambilan kuesioner dapat dilihat ditabel 3.2

Tabel 3.2

Data Sampel Penelitian

\begin{tabular}{|c|c|c|c|}
\hline No. & Keterangan & Responden & Persentase \\
\hline 1 & Jumlah kuesioner yang disebar & 54 & $100 \%$ \\
\hline 2 & Jumlah kuesioner yang kembali & 44 & $81,5 \%$ \\
\hline 3 & Jumlah kuesioner yang tidak kembali & 10 & $18,5 \%$ \\
\hline 4 & Jumlah kuesioner yang tidak dapat diolah & 1 & $1,8 \%$ \\
\hline 5 & Jumlah kuesioner yang dapat diolah & 43 & $79,6 \%$ \\
\hline
\end{tabular}

Sumber: Data primer yang diolah

Dari tabel 3.2 menunjukan total kuesioner yang disebarkan berjumlah 54 buah kuesioner atau dengan persentase sebesar 100\%. Sedangkan jumlah kuesioner yang tidak kembali sebanyak 10 kuesioner atau sebesar 18,5\%\%. Dan disaat proses pemasukan data, sebanyak 1 kuesioner atau 1,8\% kuesioner dari responden yang tidak dapat digunakan dalam 
penelitian ini, karena adanya data yang tidak diisi secara lengkap. Jumlah kuesioner yang dapat diolah sebanyak 43 kuesioner atau 79,6\%.

\section{Karakteristik Responden Penelitian}

Responden dalam penelitian ini adalah kepala sekolah, wakil kepala sekoalh beserta jajarannya pada sekolah menengah pertama negeri dan sasta di tangerang selatan yang terlibat dalam penyusunan anggaran. Adapun deskripsi mengenangi karakteristik responden dalam penelitian ini dapat dilihat pada tabel berikut:

a.

\section{Deskripsi Responden Berdsarkan Jenis Kelamin}

Tabel 3.3

Hasil Uji Deskripsi Responden Berdsarkan Jenis Kelamin Jenis Kelamin

\begin{tabular}{|cl|c|c|c|c|}
\hline & Frequency & Percent & $\begin{array}{c}\text { Valid } \\
\text { Percent }\end{array}$ & $\begin{array}{c}\text { Cumulative } \\
\text { Percent }\end{array}$ \\
\hline \multirow{2}{*}{ Valid } & laki-laki & 25 & 58,1 & 58,1 & 58,1 \\
& perempuan & 18 & 41,9 & 41,9 & 100,0 \\
& Total & 43 & 100,0 & 100,0 & \\
\hline
\end{tabular}

Sumber: data primer yang diolah

Dari tabel 3.3 diatas dapat dijelaskan bahwa sebanyak 25 orang atau sebesar 58,1\% responden didominsi oleh jenis kelamin laki-laki, dan sisanya sebanyak 18 orang atau 41,9\% responden berjenis kelamin perempuan.

b. Deskripsi Responden Berdasarkan Pendidikan Terakhir

Tabel 3.4

Hasil Uji Deskripsi Responden Berdasarkan Pendidikan Terakhir

\begin{tabular}{|rl|r|r|r|r|}
\hline & & Frequency & Percent & Valid Percent & Cumulative Percent \\
\hline \multirow{4}{*}{ Valid } & 1 & 2,3 & 2,3 & 2,3 \\
& D3 & 35 & 81,4 & 81,4 & 83,7 \\
& S1 & 7 & 16,3 & 16,3 & 100,0 \\
& S2 & 43 & 100,0 & 100,0 & \\
\hline
\end{tabular}

Sumber: data primer yang diolah

Dari tabel 3.4 diatas dapat diketahui bahwa sebagian besar responden berpendidikan terakhir strata satu (S1) dengan jumlah 35 responden atay 81,4\%. Sebanyak 7 responden atau sekitar 16,3\% berpendidikan terakhir strata dua (S2) dan sisanya sebesar 1 responden atau sebanyak $2.3 \%$ berpendidikan diploma tiga (D3). 
c. Deskripsi Responden Berdasarkan Pengalaman Kerja

Tabel 3.5

Hasil Uji Deskripsi Responden Berdasarkan Pengalaman Kerja

\begin{tabular}{|c|c|c|c|c|c|}
\hline & & Frequency & Percent & Valid Percent & Cumulative Percent \\
\hline \multirow{4}{*}{ Valid } & $<3$ & 9 & 20,9 & 20,9 & 20,9 \\
\hline & $>5$ & 13 & 30,2 & 30,2 & 51,2 \\
\hline & $3-5$ & 21 & 48,8 & 48,8 & 100,0 \\
\hline & Total & 43 & 100,0 & 100,0 & \\
\hline
\end{tabular}

Sumber: data primer yang diolah

Dari tabel 3.5 diatas menunjukan sebanyak 9 responden atau sekitar 20,9\% responden yang memiliki pengalaman kerja kurang dari tiga tahun. Sedangkan sebanyak 13 responden atau sekitar 30,2\% responden yang memiliki pengalaman kerja lebih dai lima tahun. Lalu sebanyak 21 responden atau sekitar 48,8\% responden yang memiliki pengalaman kerja antara tiga sampai lima tahun.

\section{d. Deskripsi Responden Berdasarkan Latar Belakang Pendidikan}

Tabel 3.6

Hasil Uji Deskripsi Responden Berdasarkan Latar Belakang Pendidikan

\begin{tabular}{|ll|r|r|r|r|}
\hline & Frequency & Percent & Valid Percent & Cumulative Percent \\
\hline \multirow{4}{*}{ Valid } & 19 & 44,2 & 44,2 & 44,2 \\
& Akuntansi & 8 & 18,6 & 18,6 & 62,8 \\
& Lain-Lain & 16 & 37,2 & 37,2 & 100,0 \\
& Manajemen & 43 & 100,0 & 100,0 & \\
\hline
\end{tabular}

Sumber : data primer yang diolah

Data dilihat pada tabel 3.6 jumlah responden dengan latar belakang pendidikan dibidang akuntansu berjumlah 19 orang dengan persentase 44,2\%. Latar belakang pendidikan manajemen 16 orang dengan persentase $37,2 \%$. Sedangkan 8 orang responden dengan persentase $18,6 \%$ berlatar belakang pendidikan selain akuntansi dan manajemen.

\subsection{Hasil Uji Instrumen Penelitian}

\subsubsection{Hasil Uji Statistik Deskriptif}

Variable yang digunakan dalam penelitian ini yang meliputi partisipasi anggaran, komitmen organisasi, gaya kepemimpinan dan kinerja manajerial akan diuji secara statistik deskriptif seperti yang terlihat dalam tabel 3.6 
Tabel 3.6

Hasil Uji Statistik Deskriptif

Descriptive Statistics

\begin{tabular}{|l|r|r|r|r|r|}
\hline & N & Minimum & Maximum & Mean & Std. Deviation \\
\hline PP & 43 & 12 & 30 & 21,51 & 4,361 \\
KO & 43 & 38 & 60 & 50,23 & 5,806 \\
GK & 43 & 47 & 80 & 62,56 & 7,829 \\
KM & 43 & 24 & 45 & 34,42 & 5,654 \\
Valid N (listwise) & 43 & & & & \\
\hline
\end{tabular}

Sumber: data primer yang diolah

Tabel 3.6 menjelaskan bahwa variable partisipasi anggaran jawaban minimum responden sebesar 12 dan jawaban maksimum responden sebesar 30, dengan rata-rata total jawaban 21,51 dan standar deviasi 4,361. Variable komitmen organisasi jawaban minimum responden sebesar 38 dan jawaban maksimum responden sebesar 60, dengan rata-rata total jawaban 50,23 dan standar deviasi 5,806. Variable gaya kepemimpinan jawaban minimum responden sebesar 47 dan jawaban maksimum responden sebesar 80, dengan rata-rata total jawaban 62,56 dan standar deviasi 7,829. Sedangkan variable kinerja manajerial jawaban minimum responden sebesar 24 dan jawaban maksimum responden sebesar 45, dengan rata-rata total jawaban 34,42 dan standar deviasi 5,654.

\subsubsection{Hasil Uji Kualitas Data}

\section{a. Hasil Uji Validitas}

Uji validitas digunakan umtuk mengukur valid atau tidaknya suatu kuesioner. Uji validitas dilakukan dengan membandingkan nilai $r$ hitung dengan $r$ tabel. Jika sebaliknya $r$ hitung lebih kecil dari $\mathrm{r}$ tabel maka item pertanyaan tersebut tidak valid. Dalam penelitian ini jumlah sampel (n) adalah 43, maka besarnya df adalah 43-2=41. Dengan alpha sebesar 0.05 maka didapat $\mathrm{r}$ tabel sebesar 0,301. Berikut adalah hasil pengujian validitas dari variable partisipasi anggaran, yang disajikan dalam tabel 3.7

Tabel 3.7

Hasil Uji Validitas Item Pertanyaan Partisipasi Anggaran

\begin{tabular}{|c|c|c|c|}
\hline No & $\begin{array}{c}\text { Corrected Item-Total Correlation } \\
(\mathbf{r} \text { hitung) }\end{array}$ & $\mathbf{R}$ tabel & Kriteria \\
\hline PP1 & 0,772 & 0,301 & Valid \\
PP2 & 0,825 & 0,301 & Valid \\
PP3 & 0,745 & 0,301 & Valid \\
PP4 & 0,859 & 0,301 & Valid \\
PP5 & 0,832 & 0,301 & Valid \\
PP6 & 0,832 & 0,301 & Valid \\
\hline
\end{tabular}

Sumber: data primer yang diolah 
Dari hasil pengujian dapat dilihat untuk keenam butir pertanyaan partisipasi anggaran, semua nilai $\mathrm{r}$ hitung lebih besar dari nilai $\mathrm{r}$ tabel 0,301, maka dapat disimpulkan bahwa kesemua butir pertanyaan partisipasi anggaran adalah valid. Berikut adalah hasil pengujian validitas komitmen organisasi yang disajikan dalam tabel 3.8

Tabel 3.8

Hasil Uji Validitas Item Pertanyaan Komitmen Organisasi

\begin{tabular}{|c|c|c|c|}
\hline No & $\begin{array}{c}\text { Corrected Item-Total Correlation } \\
\text { (r hitung) }\end{array}$ & R tabel & Kriteria \\
\hline KO1 & 0,555 & 0,301 & Valid \\
KO2 & 0,534 & 0,301 & Valid \\
KO3 & 0,683 & 0,301 & Valid \\
KO4 & 0,577 & 0,301 & Valid \\
KO5 & 0,345 & 0,301 & Valid \\
KO6 & 0,326 & 0,301 & Valid \\
KO7 & 0,546 & 0,301 & Valid \\
KO8 & 0,452 & 0,301 & Valid \\
KO9 & 0,381 & 0,301 & Valid \\
KO10 & 0,659 & 0,301 & Valid \\
KO11 & 0,57 & 0,301 & Valid \\
KO12 & 0,598 & 0,301 & Valid \\
\hline
\end{tabular}

Sumber: data primer yang diolah

Dari hasil pengujian dapat dilihat untuk keduabelas butir pertanyaan komitmen organisasi, semua nilai $\mathrm{r}$ hitung lebih besar dari nilai $\mathrm{r}$ tabel 0,301 , maka dapat disimpulkan bahwa kesemua butir pertanyaan komitmen organisasi adalah valid. Berikut adalah hasil pengujian validitas gaya kepemimpinan yang disajikan dalam tabel 3.9

Tabel 3.9

Hasil Uji Validitas Item Pertanyaan Gaya Kepemimpinan

\begin{tabular}{|c|c|c|c|}
\hline No & $\begin{array}{c}\text { Corrected Item-Total Correlation } \\
(\mathbf{r} \text { hitung) }\end{array}$ & R Tabel & Kriteria \\
\hline GK1 & 0,823 & 0,301 & Valid \\
GK2 & 0,343 & 0,301 & Valid \\
GK3 & 0,791 & 0,301 & Valid \\
GK4 & 0,678 & 0,301 & Valid \\
GK5 & 0,699 & 0,301 & Valid \\
GK6 & 0,648 & 0,301 & Valid \\
GK7 & 0,661 & 0,301 & Valid \\
GK8 & 0,800 & 0,301 & Valid \\
GK9 & 0,817 & 0,301 & Valid \\
GK10 & 0,715 & 0,301 & Valid \\
GK11 & 0,629 & 0,301 & Valid \\
GK12 & 0,591 & 0,301 & Valid \\
\hline
\end{tabular}




\begin{tabular}{|c|c|c|c|}
\hline No & $\begin{array}{c}\text { Corrected Item-Total Correlation } \\
\text { (r hitung) }\end{array}$ & R Tabel & Kriteria \\
\hline GK13 & 0,703 & 0,301 & Valid \\
GK14 & 0,714 & 0,301 & Valid \\
GK15 & 0,659 & 0,301 & Valid \\
GK16 & 0,546 & 0,301 & Valid \\
\hline
\end{tabular}

Sumber: data primer yang diolah

Dari hasil pengujian dapat dilihat untuk keenam belas butir pertanyaan gaya kepemimpinan, semua nilai $\mathrm{r}$ hitung lebih besar dari nilai $\mathrm{r}$ tabel 0,301, maka dapat disimpulkan bahwa kesemua butir pertanyaan komitmen organisasi adalah valid.

Berikut adalah hasil pengujian validitas kinerja manajerial yang disajikan dalam tabel 3.10

Tabel 3.10

Hasil Uji Validitas Item Pertanyaan Kinerja manajerial

\begin{tabular}{|c|c|c|c|}
\hline No & $\begin{array}{c}\text { Corrected Item-Total Correlation } \\
(\mathbf{r} \text { hitung) }\end{array}$ & $\mathbf{R}$ tabel & Kriteria \\
\hline KM1 & 0,818 & 0,301 & Valid \\
KM2 & 0,801 & 0,301 & Valid \\
KM3 & 0,885 & 0,301 & Valid \\
KM4 & 0,772 & 0,301 & Valid \\
KM5 & 0,772 & 0,301 & Valid \\
KM6 & 0,729 & 0,301 & Valid \\
KM7 & 0,57 & 0,301 & Valid \\
KM8 & 0,642 & 0,301 & Valid \\
KM9 & 0,787 & 0,301 & Valid \\
\hline
\end{tabular}

Sumber: data primer yang diolah

Dari hasil pengujian dapat dilihat untuk kesembilam butir pertanyaan kinerja manajerial, semua nilai $\mathrm{r}$ hitung lebih besar dari nilai $\mathrm{r}$ tabel 0,301, maka dapat disimpulkan bahwa kesemua butir pertanyaan komitmen organisasi adalah valid.

\section{b. Hasil Uji Reliabilitas}

Uji reliabilitas dilakukan untuk menilai konsistensi dari instrumen penelitian. Suatu instrumen penelitian dikatakan reliable jika nilai Cronchbach Alpha berada diatas 0,70 (Nunnally, 1994 dalam Ghozali, 2011:48). Berikut ini tabel yang menunjukkan hasil pengujian reliabilitas dari variable partisipasi anggaran, komitmen organisasi, gaya kepemimpinan dan kinerja manajerial.

Tabel 3.11

Hasil Uji Reliabilitas Variable Partisipasi Anggaran Reliability Statistics

\begin{tabular}{|r|r|r|}
\hline $\begin{array}{c}\text { Cronbach's } \\
\text { Alpha }\end{array}$ & $\begin{array}{c}\text { Cronbach's Alpha Based } \\
\text { on Standardized Items }\end{array}$ & N of Items \\
\hline, 935 &, 936 & 6 \\
\hline
\end{tabular}

Sumber: data primer yang diolah 
Dari tabel 3.11 menunjukkan nilai Cronbach Alpha atas variable partisipasi anggaran sebesar 0,935 sehingga dapat disimpulkan bahwa pernyataan dalam kuesioner ini realible karena mempunyai nilai Cronbach Alpha lebih besar dari 0,70. Berikut ini adalah hasil pengujian reliabilitas variable komitmen organisasi yang ditunjukkan dalam tabel 3.12.

Tabel 3.12

Hasil Uji Reliabilitas Variable Komitmen Organisasi Reliability Statistics

\begin{tabular}{|r|r|r|}
\hline $\begin{array}{c}\text { Cronbach's } \\
\text { Alpha }\end{array}$ & $\begin{array}{c}\text { Cronbach's Alpha Based on } \\
\text { Standardized Items }\end{array}$ & N of Items \\
\hline, 842 &, 851 & 12 \\
\hline
\end{tabular}

Sumber: data primer yang diolah

Dari tabel 3.12 menunjukkan nilai Cronbach Alpha atas variable komitmen organisasi sebesar 0,842 sehingga dapat disimpulkan bahwa pernyataan dalam kuesioner ini realible karena mempunyai nilai Cronbach Alpha lebih besar dari 0,70. Berikut ini adalah hasil pengujian reliabilitas variable gaya kepemimpinan yang ditunjukkan dalam tabel 3.13

Tabel 3.13

Hasil Uji Reliabilitas Variable Gaya Kepemimpinan Reliability Statistics

\begin{tabular}{|r|r|c|}
\hline $\begin{array}{c}\text { Cronbach's } \\
\text { Alpha }\end{array}$ & $\begin{array}{c}\text { Cronbach's Alpha Based } \\
\text { on Standardized Items }\end{array}$ & $\begin{array}{c}\text { N of } \\
\text { Items }\end{array}$ \\
\hline, 938 &, 938 & 16 \\
\hline
\end{tabular}

Sumber: data primer yang diolah

Dari tabel 3.13 menunjukkan nilai Cronbach Alpha atas variable gaya kepemimpinan sebesar 0,938 sehingga dapat disimpulkan bahwa pernyataan dalam kuesioner ini realible karena mempunyai nilai Cronbach Alpha lebih besar dari 0,70. Berikut ini adalah hasil pengujian reliabilitas variable kinerja manajerial yang ditunjukkan dalam tabel 3.14

Tabel 3.14

Hasil Uji Reliabilitas Variable Kinerja Manajerial Reliability Statistics

\begin{tabular}{|r|r|r|}
\hline $\begin{array}{c}\text { Cronbach's } \\
\text { Alpha }\end{array}$ & $\begin{array}{c}\text { Cronbach's Alpha Based } \\
\text { on Standardized Items }\end{array}$ & N of Items \\
\hline, 930 &, 934 & 9 \\
\hline
\end{tabular}

Sumber: data primer yang diperoleh

Dari tabel 3.14 menunjukkan nilai Cronbach $A \not p h a$ atas variable kinerja manajerial sebesar 0,930 sehingga dapat disimpulkan bahwa pernyataan dalam kuesioner ini realible karena mempunyai nilai Cronbach Alpha lebih besar dari 0,70. Hasil ini menunjukkan bahwa setiap item pernyataan yang digunakan akan mampu memperoleh data yang konsisten yang berarti bila 
pernyataan itu diajukan kembali akan diperoleh jawaban yang relatif sama dengan jawaban sebelumnya.

\subsubsection{Hasil Uji Asumsi Klasik}

\section{a. Hasil Uji Multikoloniearitas}

Bertujuan untuk menguji adana problem multiko. Umumnya dapat dilihat dari nilai tolerance dan lawannya dengan Variance Inflation Factor (VIF).

Tabel 3.15

Hasil Uji Multikoloniearitas

Coefficients $^{a}$

\begin{tabular}{|c|c|c|c|}
\hline & \multirow{2}{*}{ Model } & \multicolumn{2}{|c|}{ Collinearity Statistics } \\
\hline & & Tolerance & VIF \\
\hline \multirow{4}{*}{1} & (Constant) & & \\
\hline & PP &, 884 & 1,132 \\
\hline & $\mathrm{KO}$ & ,917 & 1,091 \\
\hline & GK & ,951 & 1,051 \\
\hline
\end{tabular}

a. Dependent Variable: KM

Sumber: data primer yang diolah

Berdasarkan tabel 3.15 diatas dapat dilihat bahwa nilai tolerance mendekati angka 1 atau lebih besar dari 0,10 dan nilai Variance Inflation Factor (VIF) disekitar angka 1 atau kurang dari 10 untuk setiap variable. Hal tersebut ditunjukkan dengan nilai tolerance partisipasi anggaran sebesar 0,884 dan VIF 1,132, komitmen organisasi nilai tolerance sebesar 0,917 dan VIF 1,091, gaya kepemimpinan nilai tolerance 0,951 dan VIF 1,051. Dengan demikian model persamaan regresi tidak menentukan problem multiko dan dapat digunakan dalam penelitian ini.

\section{b. Hasil Uji Normalitas}

Hasil uji normalitas berdasarkan output histogram disajikan pada gambar 3.1

Gambar 3.1

Hasil Uji Normalitas Menggunakan Grafik P-Plot

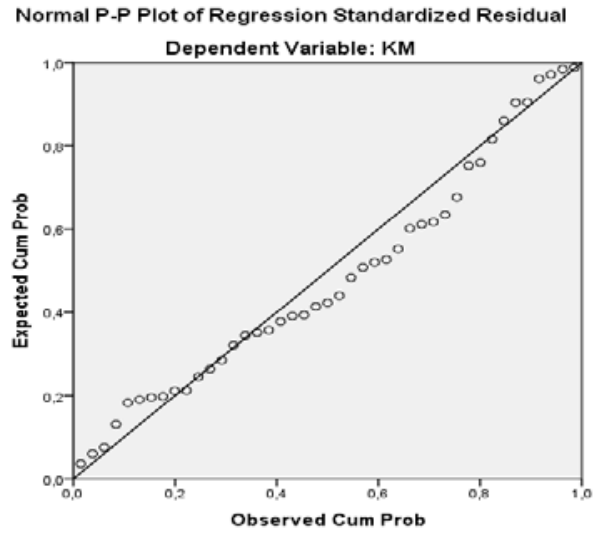

Sumber: data primer yang diolah 
Gambar 3.1 diatas dapat dijelaskan bahwa gambar tersebut menunjukkan pola distribusi yang normal. Hal tersebut dikarenakan titik-titik menyebar disekitar garis giagonal dan mengikuti arah garis diagonal. Artinya model regresi tersebut memenuhi asumsi normalitas. Berikut ini adalah hasil uji normalitas berdasarkan output histogram disajikan pada gambar 3.2

\section{Gambar 3.2}

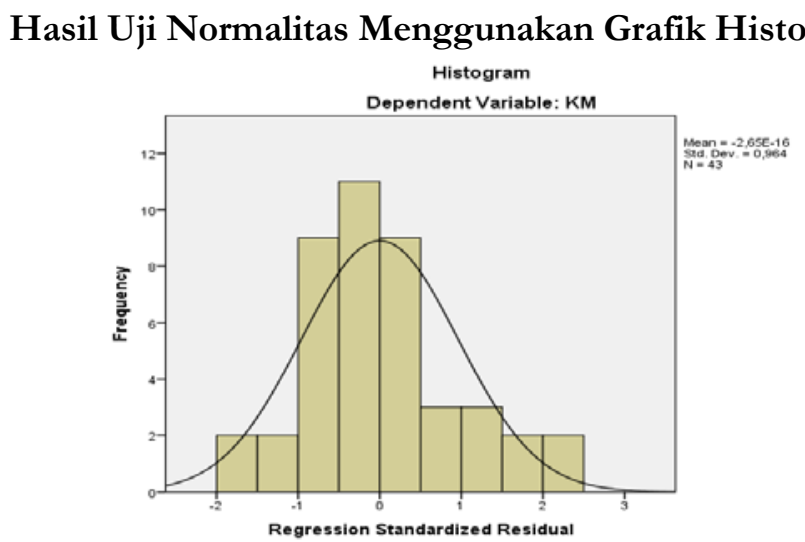

Sumber: data primer yang diolah

Gambar 3.2 diatas menunjukkan bahwa grafik histogram memenuhi pola distribusi normal. Hal tersebut dikarenakan garis pada grafik mengikuti bentuk grafik histogram. Sehingga model regresi tersebut memenuhi asumsi normalitas.

\section{c. Hasil Uji Heteroskedastisitas}

Uji heteroskedastisitas bertujuan untuk menguji apakah dalam model regresi terjadi ketidakamaan variance dari residual satu pengamatan kepengamatan yang lain, berikut akan disajikan dalam gambar 3.3

\section{Gambar 3.3}

\section{Hasil Uji Heteroskedastisitas Menggunakan Scatterplot}

Scatterplot

Dependent Variable: KM

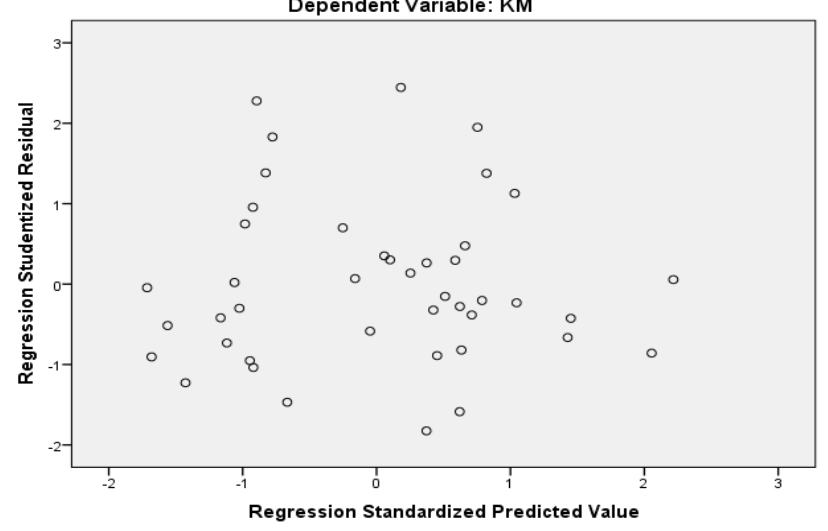

Sumber: data primer yang diolah

Berdasarkan gambar diatas, grafik tersebut menunjukkan bahwa data tersebar diatas dan dibawah angka 0 (nol) pada sumbu y dan tidak terdapat suatu pola yang jelas pada penyebaran data tersebut. Melihat keadaan seperti itu, berarti tidak terjadi heterokedatisitas pada model 
persamaan regresi, dengan demikian model regresi layak digunakan untuk memprediksi kinerja manajerial, berdasarkan variable yang mempengaruhinya, yaitu partisipasi anggaran, komitmen organisasi dan gaya kepemimpinan.

\subsection{Hasil Uji Hipotesis}

\section{a. Uji Koefisien Determinasi $\left(\mathbf{R}^{2}\right)$}

Hasil uji koefisien determinasi dapat dilihat pada tabel 3.16 dibawah ini:

Tabel 3.16

Hasil Uji Koefisien Determinasi $\left(\mathbf{R}^{2}\right)$ Variabel $\mathbf{X}_{1}, \mathbf{X}_{2}, \mathbf{X}_{3}$ dan $\mathbf{Y}$

Model Summary

\begin{tabular}{|l|r|r|r|r|}
\hline Model & \multicolumn{1}{|c|}{$\mathrm{R}$} & R Square & \multicolumn{1}{c|}{$\begin{array}{c}\text { Adjusted R } \\
\text { Square }\end{array}$} & $\begin{array}{l}\text { Std. Error of the } \\
\text { Estimate }\end{array}$ \\
\hline 1 &, $749 \mathrm{a}$ &, 561 &, 527 & 3,889 \\
\hline
\end{tabular}

a. Predictors: (Constant), GK, KO, PP

b. Dependent Variable: KM

Sumber: data primer yang diolah

Tabel 3.16 menjelaskan bahwa partisipasi anggaran, komitmen organisasi, gaya kepemimpinan dapat menjelaskan 0,527 atau 52,7\% variable kinerja manajerial. Sisanya 47,3\% dijelaskan oleh variable lain yang tidak dimasukkan dalam penelitian, seperti budaya organisasi (Brahmasari dan Suprayetno (2008:56) yang menunjukan bahwa penerapan budaya organisasi yang baik dapat meningkatkan kinerja manajerial seperti faktor toleransi resiko, tekanan pada tim, dan dukungan orang, persepsi keseluruhan ini akan menjadi budaya atau kepribadian organisasi tersebut yang mampu mendukung dan mempengaruh kepuasan kerja karyawan dan kinerja manajerial serta dampak yang lebih besar pada budaya yang lebih kuat, job relevant information (Sinuraya, 2009:36) menunjukkan bahwa kesempatan bagi manajer untuk memperoleh, tukar menukar dan menyebarkan informasi relevan dapat memfasilitasi proses pembuatan keputusan mereka, sehingga dengan informasi yang relevan tersebut akan meningkatkan kinerja, sistem reward (Kurnianingsih, 2001:63) yang menunjukkan sistem reward yang diberikan oleh perusahaan sangat mempengaruhi produktivitas dan tendensi para karyawan untuk tetap bersama organsasi atau mencapai pekerjaan lainnya. Semakin besar perhatian perusahaan terhadap kebutuhan karyawannya maka perusahaan tersebut akan mendapat timbal balik yang sesuai, yaitu maksimalisasi dalam produktivitas kerja, motivasi kerja (Gunawan, 2008:41) di mana motivasi kerja yang tinggi akan mendorong ke arah perilaku seorang pemimpin yang baik dan pada gilirannya akan meningkatkan kinerja manajer, kepuasan kerja (Karsono, 2008:55) Sedangkan kepuasan kerja dapat membentuk perilaku yang mengarah kepada kinerja yang lebih tinggi.

Komponen lain yang dapat mempengaruhi kinerja manajerial adalah total quality manajement (TQM) karena implementasi TQM mensyaratkan penyebaran visi, misi yang jelas, 
kebijakan kualitas melalui komunikasi oleh manajemen puncak, kepemimpinan manajemen yang kuat, penghargaan terhadap karyawan yang mendukung kebijakan kualitas perusahaan didukung dengan pendidikan dan pelatihan.

\section{b. Uji Signifikansi Parameter Individual (Statistik t)}

Uji statistik $\mathrm{t}$ menunjukkan seberapa jauh pengaruh satu variabel penjelas atau independen secara individual dalam menerangkan variasi variabel dependen dan digunakan untuk mengetahui ada atau tidaknya pengaruh masing-masing variabel independen secara individual terhadap variabel dependen yang diuji pada tingkat signifikansi 0,05 (Ghozali, 2011:156).

Hasil uji regresi secara parsial (uji t) ditunjukkan dalam tabel 3.17 di bawah ini:

Tabel 3.17

Hasil Uji Statistik $\mathbf{t}$

Coefficients ${ }^{\mathrm{a}}$

\begin{tabular}{|l|r|r|r|r|r|}
\hline \multirow{2}{*}{ Model } & \multicolumn{2}{|c|}{ Unstandardized Coefficients } & \multicolumn{1}{c|}{$\begin{array}{c}\text { Standardized } \\
\text { Coefficients }\end{array}$} & \multicolumn{1}{c|}{$\mathrm{t}$} & \\
\cline { 2 - 4 } & \multicolumn{1}{|c|}{$\mathrm{B}$} & Std. Error & \multicolumn{1}{c|}{ Beta } & & \\
\hline (Constant) & 4,139 & 7,949 & &, 521 &, 606 \\
PP &, 638 &, 146 &, 492 & 4,357 &, 000 \\
KO &, 403 &, 108 &, 414 & 3,735 &, 001 \\
GK &,- 059 &, 079 &,- 082 &,- 751 &, 457 \\
\hline
\end{tabular}

a. Dependent Variable: KM

Sumber: data primer yang diolah

\section{Partisipasi anggaran berpengaruh signifikan terhadap kinerja manajerial.}

Hasil uji statistik t tabel 3.17, dapat dilihat bahwa sig dari variable partisipasi bernilai 0,000 dan dengan nilai t 4,357. Hal ini menyatakan bahwa $\mathrm{Ha}_{1}$ diterima, dimana variable partisipasi anggaran berpengaruh secara signifikan terhadap kinerja manajerial, dikarenakan nilai sig partisipasi anggaran 0,000 lebih kecil dari nilai probabilitas $0,05(0,000<0,05)$. Partisipasi anggaran berpengaruh positif karena diindikasikan dengan dilibatkannya berbagai pihak dalam menyusun sebuah anggaran akan meningkatkan kinerja manajerial. Menurut Kunwaviyah dan Syafruddin (2010:32) semakin tinggi tingkat partisipasi manajer dalam proses penyusunan anggaran maka semakin baik kinerjanya. Himawan dan Ika S (2010:50) menjelaskan bahwa pemberian partisipasi kepada manajer yang lebih besar akan lebih meningkatkan pengaruh terhadap kinerja manajerial. Oleh karena itu dalam penyusunan anggaran di sekolah, manajer dalam hal ini kepala sekolah diharapkan dapat diberikan kesempatan lebih besar berpartisipasi dalam penyusunan anggaran agar kinerja manajerialnya dapat lebih meningkat.

Dengan demikian, hasil penelitian ini betentangan dengan hasil dari penelitian yang dilakukan oleh Wijayanti (2012:46) yang meneliti tentang pengaruh budaya dan komitmen organisasi serta hubungannya antara partisipasi penganggaran dan kinerja manajerial di 
perusahaan AMDK di Pasuruan. Hasil penelitiannya menunjukkan bahwa hubungan partisipasi penganggaran dengan kinerja manajerial dapat dikatakan tidak memiliki hubungan langsung.

\section{Komitmen organisasi berpengaruh signifikan terhadap kinerja manajerial.}

Pada variable komitmen organisasi dapat dilihat bahwa nilai sig sebesar 0,001 dan dengan nilai t 3,735. Hal ini menyatakan, bahwa variable komitmen organisasi memiliki nilai sig lebih kecil atau kurang dari nilai probabilitas 0,05 dimana $(0,001<0,05)$ yang berarti $\mathrm{Ha}_{2}$ diterima dimana komitmen organisasi berpengaruh secara signifikan terhadap kinerja manajerial. Komitmen organisasi berpengaruh positif terhadap kinerja manajerial karena dapat diindikasikan bahwa seseorang yang memiliki komitmen yang kuat akan cenderung menyukai pekerjaan yang ditekuninya, berupaya terlibat dengan organisasi dan memiliki loyalitas yang tinggi. Sehingga dengan hal tersebut akan meningkatkan kinerja manajerial. Hasil ini bertentangan dengan hasil penelitian Kunwaviyah dan Syafruddin (2010:43) yang menunjukkan bahwa komitmen organisasi tidak mempengaruhi kinerja manajerial.

Penelitian ini sejalan dengan penelitian yang dilakukan Nouri dan Parker, 1998 (dikutip dalam Ahmad dan Fatima, 2008) menganalisis komitmen organisasi dalam pengaruhnya pada hubungan partisipasi anggaran dan kinerja. Hasil penelitiannya menyatakan bahwa komitmen organiasi dan kinerja memiliki hubungan positif dan signifikan. Semakin tinggi komitmen terhadap organisasi maka kinerjanya akan semakin tinggi pula (Kunwaviyah dan Syafruddin, 2010:37).

Dari penelitian ini dapat disimpulkan bahwa semakin tinggi atau semakin baik komitmen organisasi maka semakin tinggi dan baik pula kinerja manajerial. Oleh sebab itu diharapkan kepala sekolah, wakil kepala sekolah, dan juga staff yang ada di sekolah untuk dapat meningkatkan komitmen organisasinya terhadap organisasi yang mereka pimpin, dengan cara menumbuhkan dan meningkatkan rasa ingin untuk berbakti bagi organisasi, mengutamakan kepentingan organisasi diatas kepentingan pribadi agar kinerja manajerial semakin meningkat. Dengan demikian, hasil penelitian ini sejalan dengan hasil dari penelitian yang dilakukan oleh Wijayanti (2012:47) yang meneliti tentang pengaruh budaya dan komitmen organisasi serta hubungannya antara partisipasi penganggaran dan kinerja manajerial di perusahaan AMDK di Pasuruan. Hasil dari penelitiannya menunjukkan bahwa hubungan komitmen organisasi dengan kinerja dapat dikatakan memiliki hubungan langsung.

\section{Gaya kepemimpinan berpengaruh positif terhadap kinerja manajerial.}

Pada variabel gaya kepemimpinan nilai signifikansinya adalah 0,457 dan dengan nilai $\mathrm{t}$ 0,751 . Ini berarti menyatakan bahwa variabel $\mathrm{Ha}_{3}$ tidak diterima, dimana variable gaya kepemimpinan berpengaruh negatif atau tidak terdapat korelasi posotif terhadap kinerja manajerial, dikarenakan nili sig gaya kepemimpinan 0,457 lebih besar dari nilai probabilitas 0,05 $(0,457>0,05)$. Gaya kepemimpinan berpengaruh negatif karena diindikasikan pada beberapa 
sekolah pimpinan masih memegang kendali total atas semua kegiatan yang ada di sekolah. Dengan pelaksanaan aktivitas manajerial kepemimpinan yang dijalankan belum tentu mempunyai dampak yang selalu posotif atau baik bagi organisasi, sebab semakin tinggi pelaksanaan aktivitas manajerial kepemimpinan dilakukan, maka akan berdampak pada penurunan kinerja organisasi dari waktu ke waktu. Pelaksanaan aktivitas kepemimpinan yang lebih banyak ke arah menekan karyawan bisa saja menyebabkan seorang karyawan dapat mencapai kepuasan dalam bekerja, tetapi belum tentu dapat membawa pengaruh yang positif dalam pembentukan kepribadian bawahan untuk ikhlas bekerja mencapai tujuan organisasi.

Hasil penelitian ini mendukung penelitian yang dilakukan oleh Noor (2007:43) yang mengungkapkan kemungkinan adanya partisipasi semu. Partisipasi semu ini bisa terjadi apabila manajemen tingkat atas memegang kendali total atas proses penyusunan anggaran dan mencari dukungan bawahannya. Dukungan ini hanya merupakan penerimaan formal dari bawahannya atas anggaran yang disusun dan bukan mencari masukan dalam menyusun anggaran. Siegel dan Marconi (1989) yang dikutip dalam Noor (2007:43) menyatakan gaya kepemimpinan yang cenderung mendikte dan tidak memberi kesempatan bawahan untuk berpartisipasi akan menyebabkan tekanan, kegelisahan dan pelemahan motivasi.

\section{c. Hasil Uji Signifikansi Simultan (Uji Statisti F)}

Uji statistik F pada dasarnya menunjukkan apakah semua variabel independen atau bebas yang dimasukkan dalam model mempunyai pengaruh bersama-sama terhadap variabel dependen/terikat yang diuji pada tingkat signifikansi 0,05 (Ghozali, 2011:153).

Hasil uji regresi secara simultan (uji F) ditunjukkan dalam tabel 3.18 di bawah ini:

Tabel 3.18

Hasil Uji Statistik F

ANOVA $^{a}$

\begin{tabular}{|l|r|r|r|r|c|}
\hline Model & Sum of Squares & \multicolumn{1}{c|}{ df } & Mean Square & F & Sig. \\
\hline Regression & 752,602 & 3 & 250,867 & 16,587 &, $000^{\mathrm{b}}$ \\
Residual & 589,863 & 39 & 15,125 & & \\
Total & 1342,465 & 42 & & & \\
\hline
\end{tabular}

a. Dependent Variable: KM

b. Predictors: (Constant), GK, KO, PP

Sumber: data primer yang diolah

Dari tabel 3.18 diatas diketahui bahwa nilai F sebesar 16,587 dengan nilai Sig sebesar 0,000, maka menandakan bahwa model regresi dapat digunakan untuk memprediksi kinerja manajerial. Dengan demikian $\mathrm{Ha}_{4}$ diterima, karena nilai $\mathrm{Sig}<0,05$ terdapat pengaruh yang signifikan antara partisipasi anggaran, komitmen organisasi, dan gaya kepemimpinan secara simultan terhadap kinerja manajerial. Dari hasil penelitian dapat disimpulkan bahwa semakin tinggi partisipasi anggaran, komitmen organisasi, dan gaya kepemimpinan semakin tinggi pula 
kinerja manajerialnya. Oleh karena itu, diharapkan Kepala Sekolah sebagai pengambil kebijakan untuk dapat lebih meningkatkan keterlibatan dirinya serta bawahannya untuk turut berpartisipasi dalam penyusunan anggaran, meningkatkan komitmen organisasinya terhadap organisasi yang mereka pimpin, dengan cara menumbuhkan dan meningkatkan rasa ingin untuk berbakti kepada organisasi, mengutamakan kepentingan organisasi di atas kepentingan pribadi agar kinerja manajerial semakin meningkat, dan meningkatkan kemampuan untuk dapat mempengaruhi karyawan atau bawahannya untuk dapat bekerja sama melakukan suatu kegiatan untuk mencapai tujuan yang diinginkan.

Siegel dan Macroni (1989) dalan Indarto dan Ayu (2011:36) menyatakan bahwa dengan partisipasi, karyawan akan dilibatkan keberadaannya dan tidak sekedar terlibat dalam tugas yang mereka kerjakan. Serta dengan adanya karyawan dilibatkan dalam proses penganggaran maka dapat mempengaruhi tingkat komitmen organisasi menjadi lebih tinggi. Penyusunan anggara partisipatif diharapkan kinerja manajer akan meningkat, dimana ketika suatu tujuan dirancang dan secara partisipasi disetujui, maka karyawan akan menginternalisasi tujuan yang ditetapkan, dan memiliki rasa tanggungjawab pribadi untuk mencapainya karena mereka ikut terlibat dalam penyusunan anggaran (Milani, 1975 dalam Sabaruddinsah 2009:25).

Berdasarkan penelitian yang dilakukan oleh Kurniawaty (2010:32) bahwa keseluruhan variable dari penelitian ini secara simultan berpengaruh terhadap kinerja manajerial. Selain itu variable partisipasi anggaran, komitmen organisasi dan gaya kepemimpinan masih terdapat variable lain yang dapat mempengaruhi kinerja manajerial seperti budaya organisasi, kecakupan anggaran dan sistem reward.

\section{KESIMPULAN DAN SARAN}

\subsection{Kesimpulan}

Bersadarkan data yang telah dikumpulkan dan hasil dari pengujian yang telah dilakukan permasalahan dengan menggunakan metode analisis regresi, maka dapat diambil kesimpulan sebagai berikut:

1. Partisipasi anggaran berpengaruh signifikan terhadap kinerja manajerial. Hasil penelitian ini mendukung penelitian dilakukan oleh Kunwaviyah dan Syafruddin (2010:14) yang menunjukkan bahwa partisipasi anggaran mempunyai pengaruh secara signifikan terhadap kinerja manajerial.

2. Komitmen organisasi berpengaruh signifikan terhadap kinerja manajerial. Penelitian ini konsisten dengan penelitian yang dilakukan Nouri dan Parker, 1998 (dikutip dalam Ahmad dan Fatima, 2008; Kunwaviyah dan Syafruddin, 201:140) yang menunjukkan variable komitmen organisasi berpengaruh secara signifikan terhadap kinerja manajerial. 
3. Gaya kepemimpinan tidak berpengaruh signifikan terhadap kinerja manajerial. Hasil ini mendukung penelitian yang dilakukan oleh Noor (2007:32), dan Sumarno (2005:43) yang menyatakan bahwa gaya kepemimpinan tidak berpengaruh signifikan terhadap kinerja manajerial.

4. Partisipasi anggaran, komitmen organisasi, dan gaya kepemimpinan bersama-sama berpengaruh signifikan terhadap kinerja manajerial.

\subsection{Saran}

Berdasarkan pembahasan dapat diajukan saran-saran sebagai berikut:

1. Peneliti selanjutnya diharapkan untuk mencoba melakukan penelitian pada populasi yang lain dengan responden yang homogyeny, sehingga diperoleh pemahaman yang lebih komprehensif.

2. Penelitian selanjutnya diharapkan dapat menambah jumlah sampel penelitian serta memperluas wilayah sampel penelitian, bukan hanya di Tangerang Selatan saja tetapi juga di kota-kota besar lainnya, sehingga dapat diperoleh hasil penelitian dengan tingkat generalisasi yang lebih tinggi.

3. Penelitian selanjutnya diharapkan dapat menggunakan metode penelitian yang berbeda seperti metode wawancara langsung kepada responden untuk memperoleh data yang lebih berkualitas.

4. Penelitian selanjutnya, disarankan tidak hanya menyebar kuesioner kepada responden, tetapi juga wawancara dan sebaiknya peneliti dapat memastikan bahwa responden mengerti maksud dari setiap butir pertanyaan yang diajukan dalam kuesioner agar hasil data yang diperoleh peneliti nantinya tidak bias dan sesuai dengan apa yang diharapkan dan yang dimaksud peneliti.

\section{REFERENSI}

Abbas, Syafrudin. 2008. 'Pengaruh Penganggran Partisipatif Terbadap Komitman Organisasi, Job-Relevant Information dan Kinerja Manajerial”. Jurnal Megadigma, Vol. 2, 2 April 2008.

Adrianto, Yogi. 2008. “Analisis Pengarub Partisipasi Penyusunan Anggaran Terhadap Kinerja Manajerial Dengan Kepuasan Kerja, Job Relevant Information dan Kepuasan Kerja Sebagai Variabel Moderating", Tesis.

Anthony, Robert N, dan Vijay Govindarajan. 2006. "Sistem Pengendalian Manajemen”, Terjemahan Fx, Kurniawan Tjakrawala. Salemba Empat. Jakarta.

Ayu Brahmasari, Ida dan Agus Suprayetno. 2008. 'Pengaruh Motivasi Kerja, Kepemimpinan dan Budaya Organisasi Terbadap Kepuasan Kerja Karyawan serta Dampaknya pada Kinerja Perusahaan (Studi kasus pada PT. Pei Hai International Wiratama Indonesia)”. Surabaya. 
Badriyah, Nurul, Ria Nelly Sari, Enni Savitri. 2011. "Pengarub Partisipasi Penyusunan Anggaran, Kejelasan Sasaran Anggaran, Kesulitan Sasaran Anggaran, Evaluasi Anggaran Dan Umpan Balik Anggaran Terbadap Kinerja Manajerial", Jurnal Universitas Riau, Pekanbaru.

Bass, B. M, dan Ronald. E. Riggio.2006. "Transformational Leadership: Second Edition”, Lawrence Erlbaum Associates, Publishers.

Bustami, Bastian dan Nurlela. 2009. "Akuntansi Biaya Melalui Pendekatan Manajerial", Penerbit Mitra Wacana Media, Edisi pertama. Jakarta.

Djalil, Muslim A, dan Fazli Syam. 2006. 'Pengarub Orientasi Profesional Terhadap Konflik Peran: Interaksi Antara Partisipasi Anggaran Dan Penggunaan Anggaran Sebagai Alat Ukur Kinerja Dengan Orientasi Manajerial". SNA IX Padang.

Eker, Melek. 2007. "The Impact Of Budget Participation On Managerial Performance Via Organizational Commitment: A Study On The Top 500 Firms In Turkey”.

Falikhatun. 2007. "Pengaruh Partisipasi Penganggaran Terbadap Budgetary Slack dengan Variabel Pemoderasi Ketidakpastian Lingkungan dan Kohesivitas Kelompok". Jurnal Akuntansi dan Keuangan. Universitas Muhammadiyah Surakarta, Volume 6, No. 2, September 2007 Halaman $207-221$.

Fibrianti, Diana dan Ikhsan Budi Riharjo. 2013. 'Pengarub Partisipasi Anggaran, Desentralisasi, Komitmen Organisasi,dan Ketidakpastian Lingkungan Terbadap Kinerja Manajerial pada Pemerintahan Kota Surabaya", Jurnal Ilmu dan Riset Akuntansi, Volume 1, Nomor 1, Januari 2013.

Ghozali, Imam. 2011. "Aplikasi Analisis Multivariate dengan Program SPSS”, Universitas Diponegoro, Semarang.

Hansen, Don R., dan Marryanne M. Mowen. 2009. "Managerial Accounting”, edisi 9th, Terjemahan Deny Arnos Kwary, Penerbit Salemba Empat, Jakarta.

Hersey, Paul dan Kenneth H. Blanchard. 1992. Manajemen Perilaku Organisasi : Pendayagunaan Sumber Daya Manusia, Erlanngga, Jakarta.

Himawan, Albertus Kukuh dan Ardianu Ika S. 2010. 'Pengaruh Komitmen Organisasi, Gaya Kepemimpinan dan Job Relevant Information (JRI) Terbadap Hubungan Antara Partisipasi Anggaran dan Kinerja

Manajerial

(Studi Empiris pada BPR di Kota Semarang)” Akses: Jurnal Ekonomi dan Bisnis, vol. 5 No. 9 , April 2010.

Horngren, Charles T. Srikant M Datar dan George Foster. 2000. "Akuntansi Biaya:Penekanan Manajerial”, PT Indeks, Edisi 11.Jakarta.

Ikhsan, Arfan, Muhammad Ishak.2005. “Akuntansi Keperilakuan”, Salemba Empat, Jakarta.

Indarto, Stefani Lily dan Stephana Dyah Ayu. 2011. "Pengaruh Partisipasi Dalam Penyusunan Anggaran Terbadap Kinerja Manajerial Perusahaan Melalui Kecukupan Anggaran, Komitmen 
Organisasi, Komitmen Tujuan Anggaran, Dan Job Relevant Information (JRI)", Seri Kajian Ilmiah, Volume 14, Nomor 1, Semarang, Januari 2011.

Indiantoro, Nur dan Bambang Supomo. 2002. "Metodologi Penelitian Bisnis untuk Akuntansi \& Manajemen”, BPFE, Yogyakarta.

Karsono. 2008. 'Pengaruh Komitmen Organisasi Terhadap Kinerja dengan Motivasi dan Kepuasan Kerja Sebagai Variabel Pemediasi”, Jurnal Akuntansi dan Bisnis, Vol. 8, No. 2, Agustus 2008.

Kunwaviyah dan Muchamad Syafruddin. 2010. "Peran Variable Komitmen Organisasi dan Inovasi pada Hubungan Penganggaran dan Kinerja Manajerial: Studi Kasus pada SKPD Kabupaten

Magelang”, Jurnal Akuntansi\&Auditing, Volume 7, no. 1, November 2010.

Kurnia, Ratnawati. 2010. 'Pengarub Budgetary Goal Characteristics Terhadap Kinerja Kanajerial Dengan Budaya Organisasi Paternalistik Dan Komitmen Organisasi Sebagai Moderating Variable”. Ultima accounting vol 2 no 2.2010 .

Mah'd, Osama. Husam Al-Khadash. Mohammed Idris Dan Abdulhadi Ramadan. 2013. "The Impact Of Budgetary Participant On Managerial Performance: Evidence From Jordania University Executives”. Journal of Applied Finance\&Banking, vol 3, no.3, 2013..

Mangkunegara, Anwar Prabu. 2005. "Evaluasi Kinerja SDM”, Cetakan Pertama PT. Refika Aditama, Bandung.

Mardiasmo. 2009. “Akuntansi Sektor Publik”, Cetakan ke empat, Penerbit Andi, Yogyakarta.

Mulyasari, Windu dan Slamet Sugiri. 2005. 'Keadilan, Komitmen pada Tujuan dan Job Relevant Information dalam Penganggaran Partisipatif', Jurnal Riset Akuntansi Indonesia, Yogyakarta.

Nafarin, M. 2004. "Penganggaran Perusahaan”. Edisi Revisi. Penerbit Salemba Empat. Jakarta.

Nor, Wahyudin. 2007. "Desentralisasi Dan Gaya Kepemimpinan Sebagai Variabel Moderating Dalam Hubungan Antara Partisipasi Penyusunan Anggaran Dan Kinerja Manajerial”, Jurnal Simposium Nasional Akuntansi X Makasar, 26-28 Juli 2007.

Nurjanah. 2008. "Pengaruh Gaya Kepemimpinan dan Budaya Organisasi terhadap Komitmen Organisasi dalam Meningkatkan Kinerja Karyawan (Studi pada Biro Lingkup Departemen Pertanian)”, Tesis, Pasca Sarjana Universitas Diponegoro, Semarang.

Riyadi, Slamet. 2007. "Pengaruh Desentralisasi, Motivasi, Dan Partisipasi Anggaran Terhadap Kinerja Manajerial Pada Perusahaan Manufaktur Yang Terdapat Dibursa Efek Jakarta. Jurnal ekonomi”.

Robbins, Stephen. P. 1996. "Perilaku organisasi. Edisi Bahasa Indonesia” PT Indeks Kelompok GRAMEDIA. Jakarta.

Rudianto. 2006. Akuntansi Manajemen: Informasi Untuk Pengambilan Keputusan. Penerbit: PT.Grasindo. jakarta.

Sabaruddinsah. 2009. "Pengaruh Partisipasi Penyusunan Anggaran Terbadap Prestasi Kerja dan Kepuasan Kerja dengan Job Relevant Information Sebagai Variabel Intervening” Jurnal Optimal, vol. 3, no. 1, Maret 2009. 
Sardjito, Bambang dan Osmad Muthaher. 2007. 'Pengaruh Partisipasi Penyusunan Anggaran Terbadap Kinerja Aparat Pemerintah Daerah : Budaya Organisasi dan Komitmen Organisasi Sebagai Variabel Moderating”, Simposium Nasional Akuntansi X, Makasar, 2007.

Sarjana, I Made, Luh Mei Wahyuni, dan I Made Sura Ambarajaya. 2012. "Pengarub Anggaran Partisipatif terhadap Kinerja Manajerial pada PT (PERSERO) Angkasa Pura 1 Bandara Ngurah Rai-Bali”. Jurnal Bisnis dan Kewirausahaan. Volume 8 Nomer 1, Maret 2012.

Sopiah. 2008. 'Perilaku Organisasi”, Andi Yogyakarta, Yogyakarta.

Sugioko, Sofian. 2007. "Faktor Pemediasi pada pengaruh Partisipasi Penganggaran Terhadap Kinerja Pejabat Struktural Perguruan Tinggi”, Akuntanbilitas, Volume 7, Nomor 1, September 2007.

Sujak, Abi. 1990. Kepemimpinan Manajer: Eksistensinya Dalam Perilaku Organisasi, Edisi I, Jakarta: Rajawali.

Sumarno. 2005. 'Pengarub Komitmen Organisasi Dan Gaya Kepemimpinan Terbadap Hubungan Anggaran Dan Kinerja Manajerial (Studi Empiris Pada Kantor Cabang Perbankan Indonesia Di Jakarta)”. Simposium Nasional Akuntansi VIII. Solo.

Tangkau, Jaqueline. 2009. "Analisis Pengarub Komitmen Organisasional dan Partisipasi Anggaran Terhadap Kinerja Manajerial dan Senjangan Anggaran (Budgetary Slack)”. Jurnal Formas, Vol. 2, No.4, Juni 2009.

Triana, Maya. Yuliusman, dan Wirmie Eka Putra. 2012. "Pengaruh Partisipasi Anggaran, Budget Emphasis, Dan Locus Of Control Terhadap Slack. Anggaran (Survei Pada Hotel Berbintang Di Kota Jambi)”, E-Jurnal Binar Akuntansi Volume 1 Nomer 1, September 2012.

Trisnaningsih, Sri. 2007. 'Independensi Auditor dan Komitmen Organisasi Sebagai Mediasi Pengaruh Pemahaman Good Governance, Gaya Kepemimpinan dan Budaya Organisasi Terbadap Kinerja Auditor", SNA X Makassar, 26-28 Juli 2007.

Wijayanti, Titik. 2012. "Pengaruh Budaya Dan Komitmen Organisasi Serta Hubungannya Antara Partisipasi Penganggaran Dan Kinerja Manajerial Perusabaan Amdk Di Pasuruan”. Jurnal Manajemen Bisnis. Volume 2 No 01 .Edisi April 2012.

Yukl, A.G. 2009. "Kepemimpinan Dalam Organisasi”, Edisi Bahasa Indonesia : Budi Supriyatno, Jakarta: PT. Indeks, 2009.

Yusfaningrum, Kusnasriyanti. 2005. "Analisis Pengarub Partisipasi Anggaran Terbadap Kinerja Manajerial Melalui Komitmen Tujuan Anggaran Dan Job Relevant Information (JRI) Sebagai Variable Intervening (Penelitian Terbadap Perusahaan Manufaktur Di Indonesia)”. Yogyakarta, 2005. 